parties must consider the wounded and the medical staff who care for them as neutral, and protect them from harm.

The public and the media must increase calls for political and diplomatic pressure to help to prevent such attacks. The scientific community, and in particular biomedical and clinical researchers and the professional bodies that represent them, must add their voices to this timely and important matter.

The need for ground rules in conflicts has been recognized since antiquity, but today's international humanitarian laws have their roots in the work of the nineteenth-century Swiss businessman, Henry Dunant. Horrified by the thousands of wounded left untreated and dying on the battlefield after the French and Sardinians crushed the Austrian army at Solferino in Italy in 1859, he proposed that states should allow, and protect, humanitarian volunteers to care for those who are wounded.

In 1863, he helped to found what was to become the International Committee of the Red Cross (ICRC). Dunant's efforts spurred 16 countries to agree the following year to the first internationally codified rules of war; the first Geneva Convention for the Amelioration of the Condition of the Wounded and Sick in Armed Forces in the Field. As well as granting neutral status to medical staff, it obliged warring parties to care for wounded enemy prisoners.

As the nature of warfare has changed, so the wording and scope of the Geneva Conventions have been regularly revised - for example in 1949 to better protect civilians. The principle of medical neutrality is more relevant today than ever, but it is under increasing threat.

Syria, where conflict sparked in 2011, is by far the worst case. As of the end of September, 313 attacks on 227 medical facilities had been reported -283 of them carried out by government forces, often using indiscriminate 'barrel bombs' dropped from helicopters. Over the same period, 679 medical staff have been killed, almost all by government forces, and scores of others have been arrested, imprisoned or tortured. The regime has also deployed chemical weapons. The health system has been all but destroyed in large parts of the country.

During peaceful protests in Turkey in 2013 and 2014, the government used violence against clinics and medical staff, and health workers have been arrested and charged with assisting criminals simply for having treated wounded protestors. Similarly, during protests against the government in Bahrain in 2013, doctors and nurses were fired from civil-service posts, then arrested and jailed for the same motive as those in Turkey. Dozens of workers dispensing polio vaccinations have been assassinated in Pakistan and Nigeria. The ICRC has identified almost 2,000 incidents of violence against patients, health workers and medical facilities in 23 countries in 2012 and 2013 alone.
These are estimates, but comprehensive monitoring of violations and data are both lacking. However, Susannah Sirkin, director of international policy and partnerships for Physicians for Human Rights, based in New York City, points out that "we can safely say that the bombing of hospitals and deliberate killing of hundreds of medics, especially in Syria, is something more extreme and extensive than we have ever seen".

Among the explanations is a lack of awareness of the Geneva Conventions by protagonists - in what are increasingly not wars
"The Geneva Conventions lack a body with teeth to ensure that the rules are respected." between nations, but smaller civil and sectarian wars, often involving non-state actors but also a poor grasp by the media and public. People may have "become inured to the extraordinary level of targeting of civilians in many conflicts in the past few decades and simply shrug at the inclusion of medical facilities as regular targets", adds Sirkin. What is worrying, she says, is that the overt targeting of humanitarian and health workers has become the "new normal", despite it being illegal under international law - and having the effect of depriving entire populations of health care, and children of vital vaccinations.

But above all, abuses happen because there is little accountability, with perpetrators operating with almost total impunity, despite their actions often clearly amounting to war crimes - or indeed crimes against humanity. The Geneva Conventions lack a body with teeth to ensure that the rules are respected, or to stop abuses when they are under way. They also lack mechanisms to investigate and prosecute abuses.

Accountability has also suffered because many of those affected are voiceless. MSF, by contrast, has both political clout and moral authority, and, for example, is robustly and rightly pressing for an independent international fact-finding commission under the Geneva Conventions into the attacks on its facilities.

Momentum to stop the attacks, led by campaigns from humanitarian groups, is building within civil society. Meanwhile, Ban Ki-moon, the secretary-general of the United Nations, and Peter Maurer, the president of the ICRC, last week issued a joint warning about the unprecedented level of violations of international humanitarian law in ongoing conflicts.

As well as the armistice, this month marks 100 years since the decision to evacuate troops from the ill-fated 1915 Gallipoli campaign, in which medical staff working under atrocious battlefield conditions suffered extensive casualties. The world has been shocked into action to protect health workers before. It must be again.

\section{Smooth operator}

\section{A tribute to the nineteenth-century polymath whose algebra lets you search the Internet.}

$\mathrm{I}$ F George Boole had lived, then he would have celebrated his 200th birthday this week. NOT that it makes any sense to say such a thing OR to write it. People do NOT live that long. And if there was one thing that George Boole is known for, it is logic. AND mathematics AND philosophy. Three things. NOT one thing.

The combination of mathematics AND logic AND philosophy is NOT easy for many people to follow OR understand. So Boole is usually associated with the three words NOT AND OR. They are called Boolean operators AND they can be combined to make AND NOT. That's because the Boolean operator OR does NOT really mean OR, which usually means AND NOT.

It is NOT always easy to follow these logical constructions when they are written in words. That is why so many people call George
Boole a genius. Because he did NOT have the same trouble. AND because he invented them OR applied them to mathematics. Without George Boole, people say that the modern world would NOT have been the same, with no computers OR electronics. Although a nice thing to say, it is probably NOT true AND someone else could have come up with the idea OR something similar. After all, Boole himself is a good example, who shows that ideas AND NOT inventions can come from an unlikely source.

He did NOT have a formal education OR academic training. $\mathrm{He}$ taught himself languages including Latin AND Greek AND calculus. He wrote scientific papers on how to represent logical relations as symbols AND algebraic equations. Despite NOT having a university education, he was appointed professor of mathematics at Queen's College Cork in Ireland.

The weather in Ireland is often NOT dry and Boole caught pneumonia after walking to the college in heavy rain. $\rightarrow$ NATURE.COM To comment online, click on Editorials at: go.nature.com/xhunqv His wife, Mary, a prominent mathematician, was NOT as skilled at medicine. She soaked her husband's sheets with water AND made him shiver with cold. It did NOT help AND, sadly, he died. 